\title{
External control of water fluoridation in a small municipality of northeast of Brazil
}

\author{
Heterocontrole da fluoretação das águas em um município de pequeno porte \\ no nordeste do Brasil
}

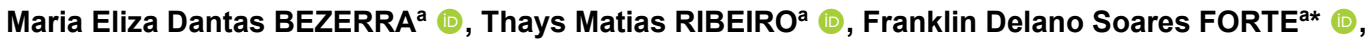 \\ Fábio Correia SAMPAIO ${ }^{\circledR}$ (1) , Jocianelle Maria Félix Fernandes NUNES ${ }^{a}$ (1) \\ aUFPB - Universidade Federal da Paraíba, João Pessoa, PB, Brasil
}

How to cite: Bezerra MED, Ribeiro TM, Forte FDS, Sampaio FC, Nunes JMFF. External control of water fluoridation in a small municipality of northeast of Brazil. Rev Odontol UNESP. 2020;49:e20200017. https://doi.org/10.1590/1807-2577.01720

\begin{abstract}
Resumo
Introdução: A fluoretação das águas de abastecimento público é uma medida importante na prevenção à cárie dentária. Objetivo: 0 objetivo do presente estudo foi avaliar e monitorar os teores de flúor nas águas de abastecimento público em um município de pequeno porte no Nordeste do Brasil. Material e método: 0 estudo apresenta uma abordagem quantitativa de caráter descritivo. Foram selecionados 3 pontos para realizar coleta das águas duas vezes no mês na zona urbana do município durante 12 meses. A concentração de flúor foi obtida pela média das três leituras das amostras analisadas para cada ponto de coleta e classificadas conforme critério proposto pelo Centro Colaborador do Ministério da Saúde em Vigilância da Saúde Bucal. Resultado: Segundo o critério utilizado (0,55 - 0,84 mg/L F), apenas 9,7\% das amostras estavam dentro do considerado ideal. Conclusão: Observou-se que a fluoretação das águas nesse município foi interrompida, pois muitas amostras de água apresentaram níveis de flúor abaixo dos valores mínimos aceitáveis.
\end{abstract}

Descritores: Cárie dentária; fluoreto; abastecimento de água.

\begin{abstract}
Introduction: Fluoridation of public water supply is an important measure in the prevention of dental caries. Objective: This study aimed to monitor the fluoride (F) concentrations of a public water supply with water fluoridation program in a small municipality in the Northeast region of Brazil. Material and method: It is a quantitative study with a descriptive approach. Three points of the urban area were selected for collecting water samples twice a month for 12 months. The average of $\mathrm{F}$ concentrations was calculated considering these three samples of each collection point at the same occasion. $\mathrm{F}$ concentrations in the water samples were determined by potentiometry and the results were classified according to the criterion proposed by criterion set down by Collaborating Center of the Brazilian Ministry of Health for Oral Health Surveillance. The samples were classified according to the best risk-benefit adjustment $(0.55-0.84 \mathrm{mg} \mathrm{F} / \mathrm{L})$. Result: Less than $10 \%$ of the samples were within the ideal range. Conclusion: It was observed that water fluoridation in this municipality was interrupted since many water samples showed f-levels below the minimal acceptable values.
\end{abstract}

Descriptors: Dental caries; fluoride; water supply.

\section{INTRODUCTION}

Fluoridation of public water supply is one of the most effective methods for preventing and controlling dental caries prevalence. In addition, it has a wide collective coverage and it is regarded as a safety method when adequate concentrations of fluoride are presented in the drinking water ${ }^{1}$. The importance of adding fluoride to public water systems has been statistically proven for over 60 years. It is considered a health strategy with great social impact. The ideal 
balance of fluoride concentration in water provides an anti-caries effect, without posing a risk to the development of dental fluorosis².

It is a recommended method by the World Health Organization (WHO) and the International Association for Dental Research (IADR), and by other influential and internationally renowned organizations, for its effectiveness, reliability, and low costs. It should be implemented and maintained whenever possible. At the beginning of the 21st century, approximately 400 million people worldwide were benefited by water fluoridation ${ }^{3}$.

In Brazil, supply water fluoridation is governed by Federal Law No. 6,050, of May 24, 1974, and regulated by Decree No.76,872, of December 22,1975, which makes the fluoridation of public water supply systems mandatory ${ }^{4-6}$. For an effective and safe fluoridation system the optimal concentration of fluoride in water is necessary. In Brazil, F-levels must vary from 0.6 up to $1.2 \mathrm{mg} / \mathrm{L}^{4}$. The maximum allowed fluoride concentration in the drinking water must not exceed $1.5 \mathrm{mgF} / \mathrm{L}$, according to the parameters of Ordinance No. 2,914/2011. The sampling plan of the Water Quality Surveillance for Human Consumption (VIGIAGUA) sets standards to be considered and guides the monitoring and quality of drinking water ${ }^{7}$.

The national oral health policy "Programa Brasil Sorridente" (Brazil Smiling Program) aimed to expand care and improve the oral health conditions of the Brazilian population. Water fluoridation is a subcomponent of the program that aims to prevent and reduce the prevalence rate of dental caries in the population dental caries and to: a) increase the number of public water supply services with fluoridation in Brazil; b) promote and improve the control systems by human and automatic operational procedures; and c) support the Water Quality Surveillance System for Human Consumption (SISAGUA) 4 .

Collaborating Center of the Brazilian Ministry of Health for Oral Health Surveillance (CECOL) was created in 2009, at the Faculty of Public Health of the University of São Paulo, with the objectives of monitoring and covering the fluoridation programs of public water supply (VIGIFLUOR) in Brazil. After meetings and discussions, CECOL proposed a criterion for classifying water according to $\mathrm{F}$ concentration and considering the temperature variation in the region, together with the benefit related to the prevention of dental caries and the risk of developing dental fluorosis 8 .

The external control is characterized for being a method of waters' periodical analysis that went through by the process of fluoridation by a public or private institution, being different from the responsible for distribution and the local's water treatment ${ }^{9}$. In Brazil, the systems of vigilance that are directed to the fluoride contents in public waters suply started in the end of 1980, since then it became more recurrent and it showed more confidence in the data achieved 9

In Brazil, in addition to the water company responsible for treating and adding fluoride in the water, any public or private agency or institution can monitor F-levels in the water and check if these levels are within the adequate range. This external control monitoring is relevant for assessing the risk-benefit balance of the method. Besides, it is necessary that the data obtained by the external control be disclosed to the population, interested entities in order to give visibility, transparency and allow corrections, when necessary $3,5,9$.

The municipality surveyed in this research is the only one to have artificial water fluoridation in Paraíba State which is located in the Northeast region of Brazil. The water fluoridation program was implemented in 2006 and this is the first external control study of F-levels in this water supply. The purpose of this study was to evaluate fluoride levels in public water supply in a small municipality in northeastern Brazil for a period of 12 months.

\section{METHOD}

\section{Study Design and Area}

This is a quantitative study with a descriptive approach carried out in a small municipality, located 84 km from the capital of Paraíba, João Pessoa, in the micro-region of Guarabira. In 2010, 
the Municipal Human Development Index (MHDI) was 0.595, being considered of medium development.

The fluoridation of public water supply in the research scenario has been carried out since 2006 , using sodium fluosilicate $\left(\mathrm{Na}_{2} \mathrm{SiF}_{6}\right)$, taking into account the local average annual temperature which is between $26.7^{\circ} \mathrm{C}$ and $32.5^{\circ} \mathrm{C}$. The Water and Sewage Autonomous Service (SAAE) is responsible for the quality of the public water supply in this municipality, for the inspection, maintenance, and distribution of water from a treatment plant in the city. About $100 \%$ of the urban population receives water from this service.

\section{Sampling and Selection of Water Collection Points}

Sample collection and analysis were carried out for a period of 12 months, in an attempt to observe the continuity of fluoride concentration in water.

The municipality in which the present research was performed is composed of approximately 14 thousand inhabitants, it has a Water Treatment Station (WTS), this one being responsible for the treatment of water in the whole city. Three sites (points) of collection were established based on population size and to facilitate access the sites were external to the households, in strategic public places under the same conditions in which water is consumed by the population ${ }^{7,10,11}$.

Water samples collection was carried out from October 2016 to September 2017, uniformly twice a month (once in the second week of the month and again in the last week). An on-site trained team was responsible for all sample collections at the three points initially chosen: SITE 01 - Water Treatment Station (WTS); SITE 02 - public square; SITE 03 - the farthest street from the water plant.

The water samples were identified and classified according to origin and date, and the information noted on labels, being deposited in a $15 \mathrm{ml}$ polyethylene container with a lid and previously cleaned with deionized water and dried at room temperature. After collection, these samples were cooled and sent to the Laboratory of Oral Biology at the Health Sciences Center of the Federal University of Paraíba. The study had a total of 72 water samples collected, that is, corresponding to 6 samples per month.

\section{Fluoride Analysis}

Initially, the calibration of the combined ion-electron specific for fluoride from ORION (9409BN) and a reference electrode (900200) was carried out, connected in an ion analyzer 710 A (ORION). The standard solutions of $6.4 ; 3.2 ; 1.6 ; 0.8 ; 0.4 ; 0.2 ; 0.1 ;$ and $0.05 \mathrm{mg} / \mathrm{L}$ of fluoride were prepared in distilled and deionized water from a standard stock solution of $100 \mathrm{mg} / \mathrm{L}$ of fluoride by serial dilution. All solutions and samples were stirred before reading. The samples were analyzed in a 1:1 ratio, with TISAB II (Total Ionic Strength Adjustor Buffer), by pipetting the volume of $1.0 \mathrm{~mL}$ of each standard plus $1.0 \mathrm{~mL}$ of TISAB II. Readings were provided in millivolts $(\mathrm{mV})$, in triplicate for each standard.

\section{Validation of Analyzes}

Millivoltage potentials were converted to $\mathrm{mg} / \mathrm{L}$, using a standard curve with a correlation coefficient $r^{2} \geq 0.99$. Only calibration curves with a variable percentage of less than 10 were considered. The millivoltage $(\mathrm{mV})$ readings, in triplicate for each standard, were transformed into fluoride concentration (content) (mg/L F) in the Windows-Excel@ program and, thus, recorded. 


\section{Data Analysis}

Fluoride concentration was obtained by averaging the three readings of the samples analyzed for each collection point. A descriptive analysis of the data was performed, and each of the samples, collected and analyzed, classified according to their fluoride concentration (Brasil, 2004). The data were classified according to the CECOL criteria, according to the Technical Consensus Document on the classification of public water supply according to fluoride concentration (CECOL, 2011). The maximum benefit and low risk was considered when fluoride concentrations were between $0.55 \mathrm{mg} / \mathrm{L} \mathrm{F}$ and $0.84 \mathrm{mg} / \mathrm{L} \mathrm{F}$.

\section{RESULT}

Table 1 shows all mean (sd) values of fluoride concentration by site in all months analyzed. Only two set of collections (in month 1 and 3) showed consistency in F-levels. However, taking the whole month, the uniformity of the fluoride content in the water was not achieved at any collecting site. Thus, only $9.7 \%$ of the samples corresponding to months 1,3 and 6 were within the acceptable range of fluoride concentration ( 0.55 up to $0.84 \mathrm{mg} / \mathrm{L})$.

It can be observed that site 1 and 2 obtained $8.3 \%$ of acceptable samples, whereas site 3 showed $12.5 \%$ of acceptable samples. The overall analysis shows that all sites presented mean values below the optimmal range with mean values close to $0.25 \mathrm{mg} / \mathrm{L}$ along the year. Apart for a set of collection in month 6 when two samples were above the accepted range, all samples showed a trend to be below $0.6 \mathrm{mg} / \mathrm{L}$ of fluoride which is the mimimum acceptable.

Table 1. Average of fluoride concentration (mg/L) according to the months studied (2016-2017)

\begin{tabular}{|c|c|c|c|c|c|}
\hline \multirow{3}{*}{ MONTH } & \multirow{3}{*}{$*$} & \multicolumn{3}{|c|}{ SITE } & \multirow{3}{*}{ Total Mean (sd) } \\
\hline & & 1 & 2 & 3 & \\
\hline & & mean (sd) & mean (sd) & mean (sd) & \\
\hline \multirow{2}{*}{1} & $1^{\text {th }}$ & $0.80(0.02)$ & $0.79(0.00)$ & $0.80(0.03)$ & $0.80(0.00)$ \\
\hline & $2^{\text {th }}$ & $0.22(0.02)$ & $0.22(0.02)$ & $0.30(0.11)$ & $0.24(0.04)$ \\
\hline \multirow{2}{*}{2} & $1^{\text {th }}$ & $0.16(0.01)$ & $0.19(0.01)$ & $0.18(0.00)$ & $0.17(0.01)$ \\
\hline & $2^{\text {th }}$ & $0.17(0.00)$ & $0.34(0.01)$ & $0.35(0.00)$ & $0.28(0.08)$ \\
\hline \multirow{2}{*}{3} & $1^{\text {th }}$ & $0.18(0.01)$ & $0.16(0.00)$ & $0.17(0.00)$ & $0.17(0.01)$ \\
\hline & $2^{\text {th }}$ & $0.66(0.03)$ & $0.70(0.04)$ & $0.56(0.02)$ & $0.64(0.06)$ \\
\hline \multirow{2}{*}{4} & $1^{\text {th }}$ & $0.05(0.00)$ & $0.05(0.00)$ & $0.04(0.00)$ & $0.04(0.00)$ \\
\hline & $2^{\text {th }}$ & $0.03(0.00)$ & $0.03(0.00)$ & $0.02(0.01)$ & $0.02(0.00)$ \\
\hline \multirow{2}{*}{5} & $1^{\text {th }}$ & $0.01(0.00)$ & $0.01(0.00)$ & $0.01(0.00)$ & $0.01(0.00)$ \\
\hline & $2^{\text {th }}$ & $0.02(0.00)$ & $0.02(0.00)$ & $0.02(0.00)$ & $0.02(0.00)$ \\
\hline \multirow{2}{*}{6} & $1^{\text {th }}$ & $0.39(0.23)$ & $0.13(0.00)$ & $0.18(0.05)$ & $0.23(0.11)$ \\
\hline & $2^{\text {th }}$ & $1.09(0.02)$ & $0.95(0.00)$ & $0.80(0.10)$ & $0.94(0.12)$ \\
\hline \multirow{2}{*}{7} & $1^{\text {th }}$ & $0.23(0.03)$ & $0.27(0.10)$ & $0.14(0.00)$ & $0.21(0.05)$ \\
\hline & $2^{\text {th }}$ & $0.24(0.09)$ & $0.18(0.00)$ & $0.16(0.02)$ & $0.19(0.03)$ \\
\hline \multirow{2}{*}{8} & $1^{\text {th }}$ & $0.12(0.01)$ & $0.11(0.00)$ & $0.08(0.01)$ & $0.10(0.01)$ \\
\hline & $2^{\text {th }}$ & $0.11(0.00)$ & $0.11(0.00)$ & $0.11(0.00)$ & $0.11(0.00)$ \\
\hline \multirow{2}{*}{9} & $1^{\text {th }}$ & $0.17(0.02)$ & $0.18(0.02)$ & $0.15(0.05)$ & $0.16(0.01)$ \\
\hline & $2^{\text {th }}$ & $0.24(0.05)$ & $0.24(0.05)$ & $0.20(0.02)$ & $0.22(0.01)$ \\
\hline \multirow{2}{*}{10} & $1^{\text {th }}$ & $0.19(0.07)$ & $0.11(0.02)$ & $0.10(0.00)$ & $0.13(0.04)$ \\
\hline & $2^{\text {th }}$ & $0.11(0.02)$ & $0.35(0.25)$ & $0.12(0.06)$ & $0.19(0.11)$ \\
\hline \multirow{2}{*}{11} & $1^{\text {th }}$ & $0.31(0.06)$ & $0.21(0.02)$ & $0.19(0.00)$ & $0.23(0.05)$ \\
\hline & $2^{\text {th }}$ & $0.20(0.00)$ & $0.17(0.00)$ & $0.18(0.01)$ & $0.18(0.01)$ \\
\hline \multirow{2}{*}{12} & $1^{\text {th }}$ & $0.42(0.34)$ & $0.19(0.01)$ & $0.05(0.00)$ & $0.22(0.15)$ \\
\hline & $2^{\text {th }}$ & $0.16(0.00)$ & $0.41(0.33)$ & $0.17(0.00)$ & $0.24(0.11)$ \\
\hline Total & - & $0.26(0.25)$ & $0.26(0.24)$ & $0.21(0.21)$ & $0.24(0.23)$ \\
\hline
\end{tabular}




\section{DISCUSSION}

The data of this survey clearly shows that the water fluoridation program in this municipality suffered several interruptions during the 12 months of monitoring. Unfortunately, this is a strong indication that the beneficial effect of fluoride exposure by the drinking water cannot be considered when evaluating dental caries prevalence in this community.

Water fluoridation interruption took place due to several reasons. The first problem faced in the municipality, which caused the water fluoridation program to pause, occurred from November 2016 to February 2017. The reason for the discontinuity of fluoridation was related to the volume of water that supplies the municipality, which underwent a water rationing process, directly affecting the fluoridation process. As there was not an exact volume of water that the city would receive each day, the addition of sodium fluosilicate became uncertain. Another difficulty encountered was the lack of financial resources for the purchase of $\mathrm{Na}_{2} \mathrm{SiF}_{6}$, generating a further interruption of fluoridation in the municipality, which occurred from April 2017 and extended until September of the same year. The temporary or definitive interruption of fluoridation causes loss of benefit on the part of the population, also occurring when the fluoride levels are below those recommended, that is, when the addition of fluoride is insufficient, making the measure ineffective.

The percentage of acceptable samples according to the criterion used was very low. In fact, $90.3 \%$ of samples were outside the acceptable range. Recently, some surveys carried out in Brazil observed similar results ${ }^{12,13}$. Studies in many parts of the country showed that $50 \%$ or more water samples were outside of the acceptable range ${ }^{14-17}$.

The municipal health surveillance has the responsibility to notify managers of the public supply systems and it is expected that they can help to solve the problem ${ }^{18}$. After obtaining the result of the analysis of public water supply for the first six months of this research, the team that performed the water analysis met with those responsible professionals for fluoridation to demonstrate the low fluoride levels obtained, aiming at solving problems.

Fluoridation of public water supply is one of the most important preventive measures for dental caries. Because it can reach a large part of the population, it can reduce inequalities between populations with different socioeconomic conditions. However, to guarantee access to fluoride, it is not enough to add it to the water supply, but it is also necessary to guarantee piped water to all households and to monitor this measure ${ }^{4,12}$.

Artificial fluoridation of public water supply has been a reality since 2006 in the researched municipality, a characteristic that highlights the municipality throughout the state since this is not a reality in the region. However, it is necessary to pay attention to the difficulties experienced in this process and to the fact that the maximum benefit of this method requires time and continuity, to result in prevention and control of the progression of the caries disease. Thus, the importance of maintaining this collective health promotion measure and the control carried out by the SAAE Company is highlighted, as well as the partnership with other agencies that can perform the external control for water analysis, aiming at improving the provision of services to the population.

In 2009, the mean dmft in this municipality was 4.45 for children with 5 years old which is regarded as high when compared to National data (mean $\mathrm{dmft}=2.43)^{19}$. Moreover, in this municipality only $21.3 \%$ of them were "caries-free" whereas in Brazil these values were $46.6 \%$ at the same period ${ }^{19,20}$. These data indicate that dental caries is a problem and water fluoridation is an important preventive measure for this population.

This municipality is the only place with water fluoridation in Paraiba. Therefore, it is necessary to pay attention to the difficulties experienced in implementing the water fluoridation since the maximum benefit of this method requires time and continuity, to control of the progression of caries disease. Thus, the importance of maintaining this collective health promotion measure and 
the control carried out by the SAAE Company is highlighted, as well as the partnership with other agencies that can perform the external control for water analysis, aiming at improving the provision of services to the population.

\section{CONCLUSION}

It was observed that water fluoridation in this municipality was interrupted since many water samples showed f-levels below the minimal acceptable values.

\section{ACKNOWLEDGEMENT}

To the Institutional Program of Scientific Initiation Grants (Pibic) of the National Council for Scientific and Technological Development (CNPq), Federal University of Paraíba, for the aid received.

\section{REFERENCES}

1. Centers for Disease Control and Prevention - CDC. Ten great public health achievements in the 20th century [Internet]. Atlanta; 2013 [cited 2018 May 24]. Available from: https://www.cdc.gov/about/history/tengpha.htm

2. Howat P, Binns C, Jancey J. New international review supports community water fluoridation as an effective and safe dental health promotion measure. Health Promot J Austr. 2015 Apr;26(1):1-3. http://dx.doi.org/10.1071/HEv26n1_ED. PMid:26149252.

3. Frazão P, Narvai PC. Water fluoridation in Brazilian cities at the first decade of the 21st century. Rev Saude Publica. 2017 May;51(0):47. http://dx.doi.org/10.1590/s1518-8787.2017051006372. PMid:28513762.

4. Brasil. Ministério da Saúde. Coordenação Geral de Saúde Bucal. Guia de recomendações para o uso de fluoretos no Brasil. Brasília; 2009.

5. Narvai PC. Cárie dentária e flúor: uma relação do século XX. Cien Saude Colet. 2000;5(2):381-92. http://dx.doi.org/10.1590/S1413-81232000000200011.

6. Frazão P, Narvai PC. Cobertura e vigilância da fluoretação da água no Brasil: municípios com mais de 50 mil habitantes. São Paulo: Faculdade de Saúde Pública da USP; 2017.

http://dx.doi.org/10.11606/9788588848252.

7. Brasil. Ministério da Saúde. Portaria no 2.914, de 12 de dezembro de 2011. Dispõe sobre os procedimentos de controle e de vigilância da qualidade da água para consumo humano e seu padrão de potabilidade. Diário Oficial da União. Brasília, 12 dezembro 2011.

8. Universidade de São Paulo - USP. Centro Colaborador do Ministério da Saúde em Vigilância da Saúde Bucal - CECOL. Documento de consenso técnico: classificação de águas de abastecimento público segundo o teor de flúor. In Seminário Vigilância da Fluoretação de Águas; 2011; São Paulo. São Paulo: Faculdade de Saúde Pública, Universidade de São Paulo; 2011.

9. Venturini CQ, Narvai PC, Manfredini MA, Frazão P. Vigilância e monitoramento de fluoretos em águas de abastecimento público: uma revisão sistemática. Rev Ambient Água. 2016 Dez;11(4):972-88. http://dx.doi.org/10.4136/ambi-agua.1929.

10. Brasil. Fundação Nacional de Saúde. Portaria no 1469, de 29 de dezembro de 2000. Aprova o controle e vigilância da qualidade da água para consumo humano e seu padrão de potabilidade. Diário Oficial da União. Brasília, 2 janeiro 2001. 
11. Brasil. Ministério da Saúde. Portaria no 518, de 25 de março de 2004. Estabelece os procedimentos e responsabilidades relativos ao controle e vigilância da qualidade da água para o consumo humano e seu padrão de potabilidade, e dá outras providências. Diário Oficial da União. Brasília, 25 março 2004.

12. Brito CS, Garbin RR, Mussi A, Rigo L. Vigilância da concentração de flúor nas águas de abastecimento público na cidade de Passo Fundo - RS. Cad Saude Colet. 2016 Dez;24(4):452-9. http://dx.doi.org/10.1590/1414-462x201600040240.

13. Peixoto DF, Alencar KP, Peixoto RF, Sousa CFM, Sampaio FC, Forte FDS. External control of fluoridation of public water supplies of the city of Jaguaribara, Ceará, Brazil. Rev Bras Prom Saúde. 2012 JulSet;25(3):271-7. http://dx.doi.org/10.5020/2255.

14. Kuhnen M, Gamba B, Narvai PC, Toassi RFC. Quality of treated water: evaluation of fluoride levels in 10 years of heterocontrol in a city of the State of Santa Catarina. Vigil Sanit Debate. 2017;5(1):1-6. http://dx.doi.org/10.3395/2317-269X.00833.

15. Bergamo ETP, Barbana M, Terada RSS, Cury JA, Fujimaki M. Fluoride concentrations in the water of Maringá, Brazil, considering the benefit/risk balance of caries and fluorosis. Braz Oral Res. 2015;29(1):47. http://dx.doi.org/10.1590/1807-3107BOR-2015.vol29.0047. PMid:25760066.

16. Marques dos Santos CC, Silva Rodrigues JC, Vigeta Lopes MR, Friozi Povinelli R, Marçal Terreri AL. Avaliação da concentração de flúor nas águas de abastecimento público: estudo retrospectivo e de heterocontrole. Rev Inst Adolfo Lutz. 2012;71(3):507-13.

17. Paredes SO, Sampaio FC, Forte FDS. External control over fluoridation of the public water supply in São Luís, MA, Brazil. Braz Res Pediatr Dent Integrated Clinic. 2014;14(2):129-40. http://dx.doi.org/10.4034/PBOCI.2014.142.07.

18. Stancari RCA, Dias FL Jr, Freddi FG. Avaliação do processo de fluoretação da água de abastecimento público nos municípios pertencentes ao Grupo de Vigilância Sanitária XV-Bauru, no período de 2002 a 2011. Epidemiol Serv Saude. 2014 Jun;23(2):239-48. http://dx.doi.org/10.5123/S167949742014000200005.

19. Fernandes JMAF, Paredes SO, Almeida DB, Sampaio FC, Forte FDS. Prevalence of dental caries and treatment needs in preschool children in a recently fluoridated brazilian town. Braz J Oral Sci. 2009 Oct-Dec;8:185-8.

20. Firmino RT, Bueno AX, Martins CC, Ferreira FM, Granville-Garcia AF, Paiva SM. Dental caries and dental fluorosis according to water fluoridation among 12-year-old Brazilian schoolchildren: a nation-wide study comparing different municipalities. J Public Health. 2018;26(5):501-7. http://dx.doi.org/10.1007/s10389-018-0901-0.

\section{CONFLICTS OF INTERESTS}

The authors declare no conflicts of interest.

\section{${ }^{*}$ CORRESPONDING AUTHOR}

Franklin Delano Soares Forte, UFPB - Universidade Federal da Paraíba, Centro de Ciências da Saúde, Departamento de Clínica e Odontologia Social, Programa de Pós-Graduação em Odontologia, Campus Universitário I, Castelo Branco I, 58051-900 João Pessoa - PB, Brasil, e-mail: franklinufpb@gmail.com

Received: March 24, 2020

Accepted: September 22, 2020 